\title{
Labyrinthe
}

1 | 1998

Numéro 1

\section{Le monde arabe à la recherche de son unité}

\section{Laurent Godmer}

\section{(2) OpenEdition}

\section{Journals}

Electronic version

URL: http://journals.openedition.org/labyrinthe/340

DOI: $10.4000 /$ labyrinthe.340

ISSN: 1950-6031

\section{Publisher}

Hermann

Printed version

Date of publication: 15 October 1998

Number of pages: 93-108

\section{Electronic reference}

Laurent Godmer, « Le monde arabe à la recherche de son unité », Labyrinthe [Online], 1 | 1998, Online since 04 March 2005, connection on 03 May 2019. URL : http://journals.openedition.org/ labyrinthe/340 ; DOI : 10.4000/labyrinthe.340

This text was automatically generated on 3 May 2019.

Propriété intellectuelle 


\title{
Le monde arabe à la recherche de son unité
}

\author{
Laurent Godmer
}

